\title{
III. EXHIBITS
}

\section{ABOUT INCREASE OF AGGREGATION OF RED CELLS WITH AN INCREASE OF TEMPERATURE. NORMAL AND ABNORMAL BLOOD (i.e. CANCER)}

\section{Dintenfass, C. D. Forbes and J. Barbenel}

Department of Medicine, University of Sydney, and Haemorheology Unit, Sydney Hospital, Sydney, Australia; University Department of Medicine, Royal Infirmary, Glasgow, Scotland; and BioEngineering

Unit, University of Strathclyde, Glasgow, Scotland

SEDIMENTATION of the red cells and their aggregation have been studied in Westergren tubes a 1room $\left(20^{\circ} \mathrm{C}\right)$ temperature and at $37^{\circ} \mathrm{C}$ and $40^{\circ} \mathrm{C}$. When corrected for plasma viscosity, data showed that the increased rate of sedimentation of red cells at higher temperatures cannot be due to the reduced plasma viscosity alone. There is an actual increase in the degree of aggregation of red cells. This pattern is true for normals and for patients suffering from cardiovascular diseases or haemophilia. However, this pattern does not have to hold always for patients suffering from malignant tumours. The following tables will show dependence of plasma viscosity, ESR st. (erythrocyte sedimentation rate, standard), ESR st.pl. (sedimentation rate corrected for plasma viscosity: ESRst $\times$ plasma viscosity), ESR st.pl.hc. (sedimentation rate corrected for plasma viscosity and extrapolated to the haematocrit of 30 per cent; this serves as a measure of aggregation of red cells). All tests were carried out on freshly collected blood samples obtained by venepuncture and anticoagulated with EDTA. This study was supported in part by the National Health and Medical Research Council of Australia.

Plasma visCosity, SEDimentation AND AGgRegation of RED CELlS AT DIFFERENT TEMPERATURES

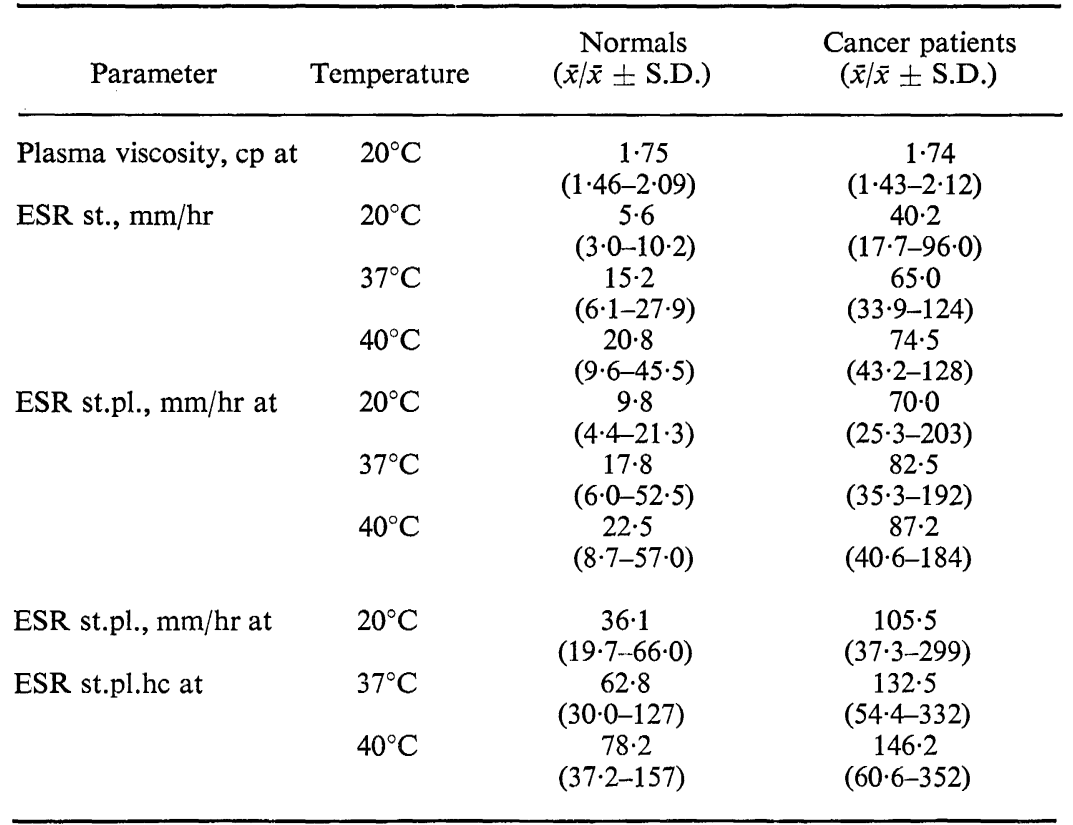

Note: Data above based on log-normal distribution. 
ChANGES IN THE SEDIMENTATION RATES AND AGGREGATION OF RED CELLS GIVEN AS RATIOS AT $37^{\circ}, 20^{\circ}, 40^{\circ}$ AND $20^{\circ} \mathrm{C}$

\begin{tabular}{lcc}
\hline \multicolumn{1}{c}{$\begin{array}{c}\text { Ratios of } \\
\text { parameters }\end{array}$} & $\begin{array}{c}37^{\circ} \mathrm{C} / \text { at } 20^{\circ} \mathrm{C} \\
\bar{x} \pm \mathrm{S} . \mathrm{D} .\end{array}$ & $\begin{array}{c}40^{\circ} \mathrm{C} / \text { at } 20^{\circ} \mathrm{C} \\
\bar{x} \pm \mathrm{S} . \mathrm{D} .\end{array}$ \\
\hline Normal controls & & \\
ESR st. & $2.951 \pm 0.921$ & $3.887 \pm 0.989$ \\
ESR st.pl.hc. & $1.821 \pm 0.475$ & $2 \cdot 203 \pm 0.595$ \\
Cancer patients & $1.532 \pm 0.436$ & $1.881 \pm 0.650$ \\
ESR st. & $1.202 \pm 0.279$ & $1.351 \pm 0.488$ \\
ESR st.pl.hc & & \\
\hline
\end{tabular}

Note: Data above based on normal distribution ESR-haematocrit correction charts are present in the following references: DINTENFASS, $\mathrm{L}$. Blood Microrheology, Butterworths, London, 1971 and Med. J. Australia 2, 827, 1970.

\title{
AN ACCESSORY TO THE WEISSENBERG RHEOGONIOMETER FOR THE MEASURE- MENT OF VISCOELASTICITY OF SURFACE LAYERS OF PROTEINS
}

\author{
R. G. KING and A. L. COPLEY
}

Hemorrhage and Thrombosis Research Laboratories and Department of Pharmacology, New York Medical College, New York, N.Y. 10029

As AN extension to our viscous resistance studies of thromboid surface layers of plasma proteins (COPLEY, A. L. Biorheology 8, 79, 1971; Copley, A. L. and KING, R. G. Thrombosis Res. 1, 1, 1972) employing the Weissenberg rheogoniometer and a combined Couette and cone and plate geometry, measurements of viscoelasticity of such layers became necessary. Although several techniques for creep measurements have

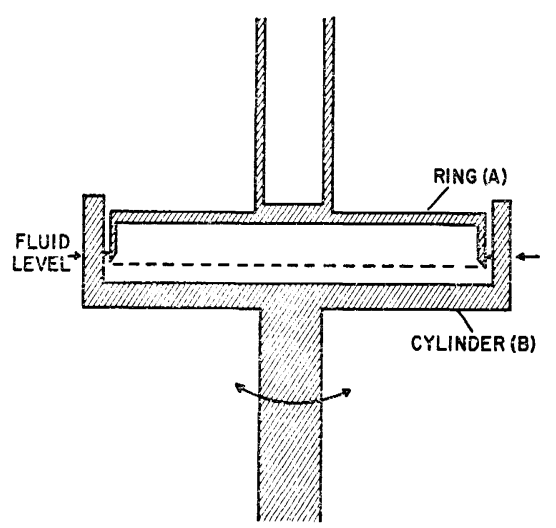

FIG. 1.

been described for the study of this parameter, no direct method has hitherto been available. This device, which we developed, consists of a ring and a cylinder (Fig. 1). The ring (A) is lowered until it penetrates the surface layer. An oscillatory motion is applied to the cylinder (B) and the amplitude ratio and phase difference between A and B are measured. From the values thus obtained the viscosity and elasticity can be calculated.

(Aided by the Office of Naval Research, United States Navy, Contract N00014-71A-0124 and the Department of Medicine and Surgery, Veterans Administration, Washington D.C.) 


\title{
TRANSISTORIZED FALLING BALL VISCOMETER FOR RAPID TESTING OF BIOLOGICAL
} AND TECHNOLOGICAL SYSTEMS

\author{
J. L. MARTin, R. M. JACOBS and A. L. Copley
}

Department of Mechanical Engineering, Newark College of Engineering, Newark N.J. 07201; Hemorrhage and Thrombosis Research Laboratories and Department of Pharmacology, New York Medical College, New York, N.Y. 10029

A TRANSISTORIZED falling ball viscometer was designed for simultaneous testing of three native human blood samples, i.e. whole blood not treated with anticoagulant, at three hydrostatic pressures. One of the principal features of the unit is that tests can be initiated within 3 min from the time a blood sample has been drawn. Changes in reffected light produced electrical outputs, as the balls passed optically sensitive transistors, spaced $0.838 \mathrm{~cm}$ center to center. These outputs from the transistors were recorded on a Texas Instrument

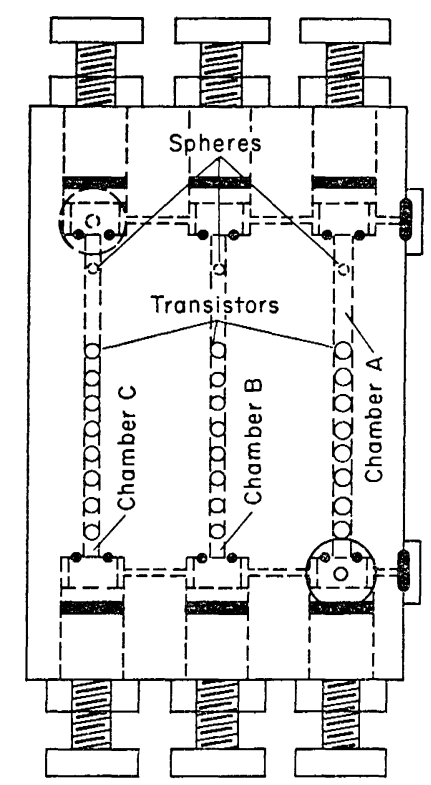

FIG. 1.

Function Writer. From the recorded trace, the time of travel for each ball between center lines of transistors was determined. The unit, a line drawing of which is shown in Fig. 1, was calibrated with G. E. Silicone Oils at various temperatures, and the findings with blood will be presented in the exhibit. The unit, designed for use with whole blood, is flexible and can be used for rapid determinations of viscosities of one to three fluids, either of biological or technological origin, in a single test.

(Aided in part by the Office of Naval Research, United States Navy, Contract N00014-71A-0124, Washington D.C.) 